\title{
Distribution of the Enzymes Oxidizing Secondary and Tertiary Amines in Pseudomonas aminovorans Grown on Various Substrates
}

\author{
By T. R. JARMAN AND P. J. LARGE \\ Department of Biochemistry, The University, Hull, HU6 ${ }_{7} R X$
}

(Received I6 March 1972; revised I June 1972)

We have previously identified three different enzymes involved in the oxidation of methyl amines by Pseudomonas aminovorans grown on methylamine or trimethylamine as sole carbon source: (i) an NAD(P)H-linked secondary amine mono-oxygenase (equation I; Eady, Jarman \& Large, I97I); (ii) an NADPH-linked tertiary amine mono-oxygenase (equation 2; Large, Boulton \& Crabbe, I972); and (iii) trimethylamine $N$-oxide demethylase, which catalyses the non-oxidative, non-hydrolytic cleavage of trimethylamine $N$-oxide to dimethylamine and formaldehyde (equation 3; Large, I97 $a$; Myers \& Zatman, I97I).

$$
\begin{gathered}
\left(\mathrm{CH}_{3}\right)_{2} \mathrm{NH}+\mathrm{NAD}(\mathrm{P}) \mathrm{H}+\mathrm{H}^{+}+\mathrm{O}_{2} \rightarrow \mathrm{CH}_{3} \mathrm{NH}_{2}+\mathrm{HCHO}+\mathrm{NAD}(\mathrm{P})^{+}+\mathrm{H}_{2} \mathrm{O}, \\
\left(\mathrm{CH}_{3}\right)_{3} \mathrm{~N}+\mathrm{NADPH}+\mathrm{H}^{+}+\mathrm{O}_{2} \rightarrow\left(\mathrm{CH}_{3}\right)_{3} \mathrm{NO}+\mathrm{NADP}^{+}+\mathrm{H}_{2} \mathrm{O} \\
\left(\mathrm{CH}_{3}\right)_{3} \mathrm{NO} \rightleftharpoons\left(\mathrm{CH}_{3}\right)_{2} \mathrm{NH}+\mathrm{HCHO} .
\end{gathered}
$$

Properties of these enzymes have been briefly reviewed by Large (I97 I $b$ ). We present here a systematic examination of the oxidative capacities of whole bacteria and cell-free extracts of $P$. aminovorans grown on various methyl amines and on succinate.

\section{METHODS}

Maintenance and growth of the organism. Pseudomonas aminovorans $\mathrm{NCIB} 9039$ was grown as described previously (Eady et al. 1971).

Preparation of extracts. Crude extracts were prepared by suspending I part wet wt of cell paste in $2.5 \mathrm{vol}$. of ice-cold $50 \mathrm{~mm}$-phosphate buffer $\mathrm{pH} 7.5$, and subjecting the suspension to the full power of a $100 \mathrm{~W}$ Dawe Soniprobe ultrasonic disintegrator (Dawe Instruments Ltd, London W. 3) for a total exposure time of $\mathrm{I} \cdot 5 \mathrm{~min}$. The temperature was maintained below $15{ }^{\circ} \mathrm{C}$ throughout. The suspension was then centrifuged for $20 \mathrm{~min}$ at $12000 \mathrm{~g}$ at $2{ }^{\circ} \mathrm{C}$ and the supernatant is referred to as the crude extract.

Oxygen estimation. Oxygen uptake by washed bacterial suspensions was measured in Warburg manometers at $30^{\circ} \mathrm{C}$. When gas phases other than air were used, the manometers and flasks were twice evacuated and flushed with the gas mixture for 2 to $3 \mathrm{~min}$. Gas mixtures were prepared by the method of Umbreit, Burris \& Stauffer (1964).

Enzyme assays

(a) Secondary amine mono-oxygenase. This was assayed spectrophotometrically at $28^{\circ} \mathrm{C}$ as previously described (Eady et al. 197I), using NADPH as electron donor.

(b) Trimethylamine $\mathrm{N}$-oxide demethylase. This was assayed at $28^{\circ} \mathrm{C}$ by measuring formaldehyde formation from trimethylamine $N$-oxide as described by Large (I97I $a$ ).

(c) Tertiary amine mono-oxygenase. This was assayed spectrophotometrically using $\mathrm{I} \mathrm{cm}$ 
light path silica cuvettes containing the following components $(\mu \mathrm{mol})$ : phosphate buffer ( $\mathrm{pH} 7.5$ ), 200; NADPH, 0.5; potassium cyanide, 3 ; trimethylamine- $\mathrm{HCl}, 2$; enzyme and water to a total volume of $3 \mathrm{ml}$. The reaction was started by addition of trimethylamine- $\mathrm{HCl}$ and followed by observing the decrease in extinction at $340 \mathrm{~nm}$ at $28{ }^{\circ} \mathrm{C}$. One unit of enzyme is the amount required to oxidize I $\mu \mathrm{mol}$ of NADPH/min under these conditions. Potassium cyanide (I $\mathrm{mm}$ ) was added because it totally inhibits trimethylamine $N$-oxide demethylase (Large, 197I $a$ ) and thus prevents conversion of trimethylamine $N$-oxide to dimethylamine, a substrate whose further oxidation is also NADPH-dependent, and the enzyme for which is present in the same extract. Higher concentrations of trimethylamine were inhibitory.

Protein determination. Protein was estimated by the method of Lowry, Rosebrough, Farr \& Randall (I95I).

Comparison of the heat stability of the activities of the amine-oxidizing enzymes in crude extracts. Samples ( $\mathrm{I} \mathrm{ml}$ ) of crude extracts of trimethylamine-grown bacteria were rapidly heated to $35^{\circ} \mathrm{C}$ and maintained at that temperature in a water bath. Samples were withdrawn at intervals, rapidly cooled to $0^{\circ} \mathrm{C}$ and enzyme activities measured.

\section{RESULTS AND DISCUSSION}

Oxidative properties of whole bacteria. When Pseudomonas aminovorans was grown on the hydrochlorides of methylamine, dimethylamine, trimethylamine or trimethylamine $N$-oxide, the washed cells readily oxidized methylamine, dimethylamine, trimethylamine $N$-oxide and sodium formate. Rates of oxidation (expressed as nmol of oxygen consumed $/ \mathrm{min} / \mathrm{mg}$ dry wt of bacteria in all cases) were of the order of 40 to 72 for methylamine, 60 to 250 for dimethylamine, 90 to 190 for trimethylamine $N$-oxide, 30 to 60 for sodium formate and 20 to 30 for formaldehyde. (The rate of oxygen consumption in the absence of substrate, which has not been subtracted, was 4 to I5.) Methanol was not oxidized. Trimethylamine was poorly oxidized (rates I 5 to 25), except by cells grown on it, when the rate rose to 200 . There was no detectable lag phase in the oxidation of these substrates by cells grown on any of the other substrates. Cells grown on succinate oxidized only succinate and formaldehyde; there was no detectable oxidation of amines. Evidence that separate enzymes catalyse the oxidation of each amine is provided by the observation that oxidation of methylamine by intact bacteria was $78 \%$ inhibited by $72 \mu \mathrm{M}$-semicarbazide- $\mathrm{HCl}$ while dimethylamine and trimethylamine $\mathrm{N}$-oxide oxidation were each only inhibited by $32 \%$, and trimethylamine oxidation was not affected. The oxidation of dimethylamine was $98 \%$ inhibited by $\mathrm{I} \%(\mathrm{v} / \mathrm{v})$ carbon monoxide in air, whereas methylamine oxidation was not affected.

The oxidative properties of intact cells thus differ from those observed in Pseudomonas sp. Ms by Kung \& Wagner (1970), since lags in the oxidation of amine substrates by bacteria grown on other amine substrates were not observed. This agrees with the observations of Leadbetter \& Mineo (I970). It may represent differences in permeability. The inhibition of dimethylamine oxidation by carbon monoxide would be expected, since the isolated enzyme is inactivated by low concentrations of this gas (Eady et al. 1971).

Distribution of the enzymes of amine oxidation in extracts of cells grown on amines or succinate. Table I shows that the secondary amine mono-oxygenase and trimethylamine $N$-oxide demethylase activities are present in bacteria grown on all the amines, but not in bacteria grown on succinate. The tertiary amine mono-oxygenase in contrast is barely detectable except in bacteria grown on trimethylamine. No significant mono-oxygenase or dehydrogenase activity towards primary amines was detected in extracts of the organism grown on any amine substrate. 
Table I. Activity of the secondary amine mono-oxygenase system, trimethylamine $\mathrm{N}$-oxide demethylase and the tertiary amine mono-oxygenase in extracts of Pseudomonas aminovorans grown on various substrates

Ultrasonic extracts were prepared and enzyme assays performed as described in Methods. For both mono-oxygenases, the electron donor was NADPH.

Specific activity $\mathrm{nmol} / \mathrm{min} / \mathrm{mg}$ protein

(Figures in parentheses denote relative activities, methylamine-grown cells $=\mathrm{I} \cdot 0$ )

\section{Carbon source} for growth

Methylamine

Dimethylamine

Trimethylamine $N$-oxide

Trimethylamine

Sodium succinate

Protein concn.
of extract
(mg/ml)
$8 \cdot 3$
$10 \cdot 5$
$10 \cdot 9$
$9 \cdot 4$
$15 \cdot 4$

Trimethylamine
$N$-oxide
demethylase

$250(1.0)$
$17(0.07)$
$173(0.69)$
$20(0.08)$
$4(0.02)$

Tertiary amine mono-oxygenase

$$
\begin{gathered}
48(\mathrm{I} \cdot 0) \\
173(3 \cdot 6) \\
124(2 \cdot 6) \\
209(4 \cdot 3) \\
0(0)
\end{gathered}
$$

$$
\begin{gathered}
5(\text { I } \cdot 0) \\
\text { I } 4(2 \cdot 8) \\
3(0 \cdot 6) \\
64 \text { I ( I } 28 \cdot 0) \\
2(0 \cdot 4)
\end{gathered}
$$

The different distribution of the tertiary amine mono-oxygenase in bacteria grown on different amine substrates suggests that it may be under separate inductive or repressive control from the other two enzymes. Certain anomalies are presented by these latter enzymes. It is not possible to be certain at this stage that the secondary amine mono-oxygenase and trimethylamine $\mathrm{N}$-oxide demethylase do not play any role in bacterial growth on methylamine, although the simplest interpretation of the oxidation pathway, namely trimethylamine $\rightarrow$ trimethylamine $N$-oxide $\rightarrow$ dimethylamine $\rightarrow$ monomethylamine, would suggest that their presence in methylamine-grown bacteria is not essential. If this were the case, it is strange that the activity of the demethylase should actually be higher in bacteria grown on methylamine, although this has been consistently observed. It is conceivable that the two enzymes are always induced together by growth on amines, in which case their presence in methylamine-grown bacteria might be gratuitous. The failure to detect an enzyme able to oxidize methylamine in cell-free extracts also remains to be explained.

Heat stability of the amine-metabolizing enzymes. The three enzymes differ markedly in their heat stability. At $35^{\circ} \mathrm{C}$, the half-life in crude extracts of the secondary amine monooxygenase was about $3 \mathrm{~min}$, that of the tertiary amine mono-oxygenase was about I I min, while the trimethylamine $N$-oxide demethylase lost no activity over $30 \mathrm{~min}$ at this temperature.

This work was supported in part by the Science Research Council. T.R.J. thanks the Medical Research Council for a research training scholarship.

\section{REFERENCES}

EADY, R. R., JARMAN, T. R. \& LARGe, P. J. (197I). Microbial oxidation of amines. Partial purification of a mixed-function secondary-amine oxidase system from Pseudomonas aminovorans that contains an enzymically active cytochrome-P-420-type haemoprotein. Biochemical Journal 125, 449-459.

KUNG, H.-F. \& WAGNER, C. (1970). Oxidation of $\mathrm{C}_{1}$ compounds by Pseudomonas sp. MS. Biochemical Journal I16, 357-365.

LARGe, P. J. (I97 I $a$ ). Non-oxidative demethylation of trimethylamine $N$-oxide by Pseudomonas aminovorans. FEBS Letters $18,297-300$.

LARGe, P. J. (I97I b). The oxidative cleavage of alkyl-nitrogen bonds in micro-organisms. Xenobiotica $\mathbf{r}$, $457-467$. 
Large, P. J., Boulton, C. A. \& Crabbe, M. J. C. (1972). The NADPH- and oxygen-dependent $N$-oxygenation of trimethylamine by Pseudomonas aminovorans. Biochemical Journal 128, 137 P-138 P.

LeAdBetTer, E. R. \& Mineo, L. (1970). Bacterial oxidation and assimilation of short-chain aliphatic monoamines. Bacteriological Proceedings, p. 62.

Lowry, O. H., Rosebrough, N. J., Farr, A. L. \& Randall, R. J. (I95I). Protein measurement with the Folin phenol reagent. Journal of Biological Chemistry 193, 265-275.

Myers, P. A. \& ZATMAN, L. J. (I97I). The metabolism of trimethylamine $N$-oxide by Bacillus PM6. Biochemical Journal I21, IOP.

Umbreit, W. W., Burris, R. H. \& Stauffer, J. F. (1964). Manometric Techniques, 4th edn, p. 69. Minneapolis: Burgess Publishing Co. 